\title{
Analisis Kebijakan Pembatasan Sosial Berskala Besar (PSBB) dalam Penanggulangan dan Pencegahan COVID-19 di Kota Depok
}

\section{Policy Analysis of Large-Scale Social Restrictions (PSBB) in Management and Pre- vention of COVID-19 in Depok City}

Julia Christy Labetubun ${ }^{1}$, Anggun Rachmawati ${ }^{1}$, Febby Zuriani Fitria ${ }^{1}$, Yayu Mukaromah ${ }^{1}$, Yudith Rachmadiah $^{1}$ dan Hadi Pratomo ${ }^{1 *}$

${ }^{1}$ Departemen Pendidikan Kesehatan dan Ilmu Perilaku, Fakultas Kesehatan Masyarakat, Universitas Indonesia, Kampus UI Depok 16424, Indonesia

*Korespondensi penulis:

pratomohadi@gmail.com
Diterima (Recieved)

Direvisi (Revised)

Diterima untuk diterbitkan (Accepted)
: 23 Februari 2021

: 21 Desember 2021

: 25 Desember 2021

\begin{abstract}
ABSTRAK
Latar Belakang. COVID-19 masuk di Indonesia pertama kali di Kota Depok, pada tanggal 2 Maret 2020. Penyebaran masif mengharuskan negara-negara terindikasi memberlakukan kebijakan ketat. Kebijakan yang diberlakukan Indonesia adalah Pembatasan Sosial Berskala Besar (PSBB). Dinyatakan sebagai zona merah, Kota Depok melalui Keputusan Gubernur Jawa Barat No.443/Kep.221-Hukham/2020 menetapkan pemberlakuan PSBB dimulai tanggal 15 April 2020.

Tujuan. untuk mengindentifikasi dan menganalisa pelaksanaan kebijakan PSBB di Kota Depok serta merumuskan rekomendasi strategis kebijakan pelaksanaan PSBB

Metode. Menggunakan media content analysis sebagai metode pengumpulan data kebijakan PSBB di Kota Depok, kemudian menganalisisnya menggunakan pendekatan segitiga kebijakan dan teknik analisis SWOT

Hasil. Terdapat 23 Kebijakan Pemerintah Kota dalam menanggulangi COVID-19 di Kota Depok. enam Diantaranya terkait pelaksanaan PSBB dan dua peraturan terkait sanksi bagi pelanggar PSBB. PSBB diaplikasikan dalam empat tahapan perpanjangan dan satu tahap lanjutan menuju PSBB Proporsional.

Kesimpulan. Tahap perpanjangan Kebijakan PSBB berhasil mengubah status Kota Depok menjadi zona kuning dengan nilai $\mathrm{Rt}=$ 0,54 pada tanggal 8 Juni 2020 sehingga siap melaksanakan PSBB Proporsional.
\end{abstract}

Kata Kunci: COVID-19, Kebijakan PSBB, Analisis Kebijakan

\section{ABSTRACT}

Background. COVID-19 entered Indonesia first in Depok City on $2^{\text {nd }}$ March 2020. Massive spread requires infected countries to enact strict policies. The policy chosen by Indonesia is a Large-Scale Social Restrictions Policy (PSBB). Declared as a red zone, Depok City, through the West Java Governor Decree No.443/2020, stipulates the implementation of PSBB on $15^{\text {th }}$ April 2020.

Objective. to identify and analyze the implementation of PSBB policies in Depok City and formulate strategic recommendations for PSBB implementation policies

Method. The method used media content analysis to collect PSBB policy data in Depok City, then analyzing it using a policy triangle approach and SWOT analysis techniques.

Results. There are 23 Local Government Policies to tackle COVID-19 in Depok City. Six of them implemented the PSBB and two regulations relating to the sanction for PSBB violators. The PSBB was applied in 4 stages of extension and 1 stage to continue the Proportional PSBB.

Conclusion. The extension stages of PSBB policy have successfully changed to be the yellow zone with Rt $=$ 0,54 on $8^{\text {th }}$ June 2020. Therefore, Depok City is ready to implement Proportional PSBB.

Keywords: COVID-19, PSBB Policy, Policy Analysis

\section{LATAR BELAKANG}

Penyebaran new emerging disease yang berawal pada tanggal 31 Desember 2019 di Kota Wuhan, China, memunculkan 59 kasus gangguan pernapasan (pneumonia). Tepat di tanggal 27 Januari 2020, WHO melaporkan telah terjadi penularan masif dari manusia ke manusia. Pada tanggal 30 Januari 2020 WHO menetapkan 2019-nCov sebagai Public Health Emergency of International Concern (PHEIC)/ Kedaruratan Kesehatan Masyarakat yang 
Meresahkan Dunia (KKMMD)., ${ }^{1,2}$ Coronavirus secara resmi juga disebut dengan SARSCoV-2 (Severe Acute Respiratory Syndrome Corona Virus 2), karena secara genetik berhubungan dengan virus Corona yang menyebabkan pandemi SARS di tahun 2003. 3,4

Sejak WHO mengumumkan sebagai pandemi global pada 11 Maret 2020, penambahan penyebaran COVID-19 telah mencapai 118 negara. ${ }^{1}$ Pada tanggal 20 Juni 2020 dilaporkan melalui Situation Report-152 oleh WHO, total kasus konfirmasi sebanyak 8.465.085 dengan 454.258 kematian, yang telah tersebar di 216 negara/wilayah. ${ }^{5,6}$

Penyebaran masif COVID-19 mengharuskan negara-negara memberlakukan kebijakan ketat, seperti halnya Korea Selatan yang melakukan skrining massal dan pelaksanaan drive-thru and walking-thru, ${ }^{7,8}$ Amerika Serikat dengan social distancing. ${ }^{9}$ Ada 107 negara yang memberlakukan national school closures atau school social distancing, ${ }^{10}$ diantaranya China dan Singapura yang mendahulukan keputusan ini untuk sekaligus mempersiapkan metode belajar abad-21. ${ }^{11}$ Pemberlakuan kebijakan lockdown (karantina wilayah) yang dilakukan oleh 18 negara pertama yang tercatat pada bulan April 2020, diantaranya; China, Italia, Spanyol, Prancis, dan beberapa negara lainnya termasuk Indonesia. ${ }^{12}$

Sebagai salah satu bentuk kewaspadaan, Indonesia melakukan pembatasan penerbangan dari China dari tanggal 03 Februari 2020. ${ }^{2}$ Kasus pertama COVID-19 di Indonesia pertama kali di Kota Depok pada tanggal 02 Maret 2020. ${ }^{6}$

Seperti halnya Jerman yang memberlakukan partial lockdown, ${ }^{12,13}$ Indonesia mengacu Undang-Undang No. 6 Tahun 2018 tentang Kekarantinaan Kesehatan ${ }^{14}$ juga memberlakukan partial lockdown atau social restriction tanpa karantina wilayah. ${ }^{12}$ Kebijakan ini kemudian disebut Pembatasan Sosial Berskala Besar (PSBB) yang ditetapkan pada 31 Maret 2020 melalui PP No.21 Tahun $2020^{15}$ dan implementasinya diatur dalam Permenkes No.9 Tahun 2020 tentang Pedoman Pelaksanaan PSBB. ${ }^{16}$

Melalui Keputusan Gubernur Jawa Barat No. 443/Kep.221-Hukham/2020 menetapkan pemberlakuan PSBB di Kabupaten Bogor, Kota Bogor, Kota Depok, Kabupaten Bekasi, dan Kota Bekasi selama 14 hari mulai 15 April hingga 28 April 2020. ${ }^{17}$ Setelah 14 hari, diketahui terdapat $50 \%$ wilayah Jawa Barat memasuki zona merah. Demikian pula disampaikan pada tanggal 4 Mei 2020 oleh Wali Kota Depok bahwa Kota Depok memasuki zona merah karena telah menyebar ke 56 kelurahan dari total 63 kelurahan. ${ }^{7}$

Pada 16 Juni 2020, Satuan Gugus Tugas Percepatan Penanganan COVID-19 Kota Depok melaporkan sudah terdapat 678 kasus COVID-19 terkonfirmasi, 433 orang dinyatakan sembuh, dan 34 orang dinyatakan meninggal dunia. ${ }^{6}$ Dengan demikian, Gubernur Jawa Barat menetapkan untuk memperpanjang PSBB hingga 26 Juni 2020 dan mengevaluasi kembali wilayah menurut zona sebelum PSBB Proporsional dilanjutkan. ${ }^{18}$

Hasil riset dan simulasi eksponensial yang dilakukan oleh Urban Policy untuk menge-tahui efektivitas PSBB I dan II menemukan bahwa kebijakan PSBB di Kota Depok belum optimal terkait dengan instrumen sanksi hukum yang tidak detail bagi pelanggar PSBB, serta keterbatasan dan tidak efektifnya operasional pengawasan jumlah check point di Kota Depok. ${ }^{19-22}$

Berdasarkan hasil riset tersebut peneliti melakukan identifikasi lanjut terkait kebijakan PSBB penanganan COVID-19 di Kota Depok menggunakan pendekatan segitiga kebijakan dan teknik analisis SWOT. Penelitian ini bertujuan untuk menganalisa pelaksanaan kebijakan PSBB di Kota Depok serta ikut berkontribusi memberikan rekomendasi strategis terkait kebijakan dalam menata kelancaran pelaksanaan PSBB Proporsional.

\section{METODE}

Artikel ini menggunakan metode media content analysis ${ }^{23-25}$ sebagai tool pengumpulan data sekunder yang berupa; (1) Undang-Undang/Peraturan Pemerintah/Surat Edaran /Keputusan Pemerintah Pusat atau Daerah; (2) situs website resmi Pemkot Depok yakni depok.go.id; (3) media massa/media info online lokal resmi Kota Depok: depok.pikiranrakyat.com dan www.radardepok.com; (4) akun resmi Instagram @pemkotdepok (5) media masa/media info online nasional resmi lainnya seperti cnnindonesia.com, cnbc indo- 
nesia.com, megapolitan.kompas.com, sindonews.com; serta (6) siaran konferensi pers melalui media sosial: YouTube channel KOMPASTV dan BeritaSatu yang dikumpulkan dari bulan Mei hingga Juni 2020.

Tiga tahapan pelakasanaan analisa meliputi: pertama, mengidentifikasi dokumen kebijakan Pemkot Depok dari tanggal 14 Maret hingga 6 Juni 2020 dalam timeline table; kedua, melakukan identifikasi kebijakan menggunakan Policy Triangle, ${ }^{26-31}$; ketiga, melakukan SWOT kebijakan yang mengacu pada International Journal of Environment Research and Public Health yang berjudul "Strengths, Weaknesses, Opportunities and Threats (SWOT) Analysis of China's Prevention and Control Strategy for the COVID-19 Epidemic" tahun 2020 untuk mengekstrak dan menganalisis faktor internal dan eksternal kebijakan PSBB di Kota Depok. ${ }^{24}$ Analisa yang dilakukan dirincikan dalam penguraian komponen Policy Triangle yang mengacu pada International Article: Archive Iran Medicine dengan judul "COVID19 Pandemic and Comparative Health Policy Learning in Iran" tahun $2020^{23}$.

\section{HASIL}

Berdasarkan data sekunder yang didapatkan, Wali Kota Depok sebagai aktor pembuat kebijakan telah mengeluarkan 23 kebijakan yang terkait tentang pemberlakuan dan pelaksanaan PSBB dan Peraturan terkait sanksi bagi pelanggar PSBB di wilayah Kota Depok (Tabel 1).

Dari total 23 kebijakan yang ada, terda pat enam kebijakan terkait pelaksanaan PSBB Kota Depok dalam rentang waktu 12 April hingga 4 Juni 2020. Surat Keputusan Wali Kota Depok yang dikeluarkan pada tanggal 12 April 2020 berisi tentang penetapan awal PSBB di Kota Depok yaitu 15 April 2020, kemudian menetapkan perpanjangan PSBB yang dilakukan sebanyak 4 tahapan berakhir di tanggal 4 Juni 2020. Penetapan PSBB Proporsional di Kota Depok selanjutnya diberlakukan pada tanggal 2 Juli 2020. Dengan rentang waktu yang cukup lama, kebijakan yang dikeluarkan sangat mempengaruhi seluruh komponen masyarakat di berbagai sektor baik pendidikan, kesehatan, sosial dan ekonomi, yang dapat dilihat pada Tabel 2 .

Tabel 1. Timeline Identifikasi Kebijakan

\begin{tabular}{|c|c|c|c|c|}
\hline $\begin{array}{c}\text { Tanggal } \\
\text { Terbit }\end{array}$ & Masa Berlaku & $\begin{array}{l}\text { Lembaga } \\
\text { Penerbit }\end{array}$ & Judul Kebijakan & Referensi \\
\hline $\begin{array}{l}14 \text { Maret } \\
2020\end{array}$ & $\begin{array}{l}16 \text { Maret }-30 \\
\text { Maret } 2020\end{array}$ & $\begin{array}{c}\text { Wali Kota } \\
\text { Depok }\end{array}$ & $\begin{array}{l}\text { Tindak Lanjut Pencegahan Penye- } \\
\text { baran Corona Virus Disease } \\
\text { (COVID-19) di Kota Depok }\end{array}$ & $\begin{array}{l}\text { Surat Edaran Wali Kota Depok } \\
\text { Nomor 443/132-Huk/Dinkes Tahun } \\
2020\end{array}$ \\
\hline $\begin{array}{l}18 \text { Maret } \\
2020\end{array}$ & $\begin{array}{l}18 \text { Maret-29 Mei } \\
2020\end{array}$ & $\begin{array}{l}\text { Wali Kota } \\
\text { Depok }\end{array}$ & $\begin{array}{l}\text { Penetapan Status Tanggap Darurat } \\
\text { Bencana Corona Virus Disease } \\
2019 \text { (COVID-19) di Kota Depok }\end{array}$ & $\begin{array}{l}\text { Surat Keputusan Wali Kota Depok } \\
\text { Nomor } \\
360 / 137 / \text { Kpts/DPKP/Huk/2020 } \\
\text { Tahun } 2020\end{array}$ \\
\hline $\begin{array}{l}18 \text { Maret } \\
2020\end{array}$ & $\begin{array}{l}19 \text { Maret }-31 \\
\text { Maret } 2020\end{array}$ & $\begin{array}{l}\text { Wali Kota } \\
\text { Depok }\end{array}$ & $\begin{array}{l}\text { Penyesuaian Sistem } \quad \text { Kerja } \\
\text { Aparatur Sipil Negara Dalam } \\
\text { Upaya Pencegahan Penyebaran } \\
\text { Corona Virus Disease } 19 \text { (COVID- } \\
\text { 19) Di Lingkungan Pemerintah } \\
\text { Daerah Kota Depok. }\end{array}$ & $\begin{array}{l}\text { Surat Edaran Wali Kota Depok } \\
\text { Nomor: } 800 / 141-H u k / B K P S D M \\
\text { Tahun } 2020\end{array}$ \\
\hline $\begin{array}{l}25 \text { Maret } \\
2020\end{array}$ & $\begin{array}{l}30 \text { Maret }-11 \\
\text { April }\end{array}$ & $\begin{array}{l}\text { Wali Kota } \\
\text { Depok }\end{array}$ & $\begin{array}{l}\text { Perpanjangan Masa Belajar Di } \\
\text { Rumah Bagi Peserta Didik PAUD } \\
\text { /TK/RA, SD/MI, SMP/MTS, SMA } \\
\text { /SMK/MA Dan Lembaga Pendi- } \\
\text { dikan Non Formal Dalam Upaya } \\
\text { Pencegahan Penyebaran Corona } \\
\text { Virus Disease } 19 \text { (COVID-19) Di } \\
\text { Kota Depok. }\end{array}$ & $\begin{array}{l}\text { Surat Edaran Wali Kota Depok } \\
\text { Nomor 420/142-HUK/DISDIK } \\
\text { Tahun } 2020\end{array}$ \\
\hline $\begin{array}{l}28 \text { Maret } \\
2020\end{array}$ & $\begin{array}{l}30 \text { Maret }-11 \\
\text { April } 2020\end{array}$ & $\begin{array}{l}\text { Wali Kota } \\
\text { Depok }\end{array}$ & $\begin{array}{l}\text { Himbauan Pelaksanaan Bekerja } \\
\text { Dari Rumah }(W F H) \text { Untuk } \\
\text { Kegiatan Perkantoran, Perusahaan/ } \\
\text { Pelaku Usaha Dan Pemilik Usaha }\end{array}$ & $\begin{array}{l}\text { Surat Edaran Wali Kota Depo } \\
\text { Nomor: 560/152-Disnaker Tahun } \\
2020\end{array}$ \\
\hline
\end{tabular}




\begin{tabular}{|c|c|c|c|c|}
\hline $\begin{array}{c}\text { Tanggal } \\
\text { Terbit }\end{array}$ & Masa Berlaku & $\begin{array}{l}\text { Lembaga } \\
\text { Penerbit }\end{array}$ & Judul Kebijakan & Referensi \\
\hline & & & $\begin{array}{l}\text { Dalam Rangka Mencegah } \\
\text { Penyebaran COVID-19. }\end{array}$ & \\
\hline $\begin{array}{l}30 \text { Maret } \\
2020\end{array}$ & $\begin{array}{l}30 \text { Maret }-21 \\
\text { April } 2020\end{array}$ & $\begin{array}{l}\text { Wali Kota } \\
\text { Depok }\end{array}$ & $\begin{array}{l}\text { Perpanjangan Masa Penyesuaian } \\
\text { Sistem Kerja ASN Dan Pegawai } \\
\text { Non ASN Dalam Upaya } \\
\text { Pencegahan Penyebaran COVID- } \\
19 \text { Di Lingkungan Pemerintah } \\
\text { Daerah Kota Depok. }\end{array}$ & $\begin{array}{l}\text { Surat Edaran Wali Kota Depok No. } \\
800 / 155-\text { Huk/BKPSDM Tahun } \\
2020\end{array}$ \\
\hline $\begin{array}{l}1 \text { April } \\
2020\end{array}$ & $\begin{array}{l}\text { 1 April sampai } \\
\text { terbitnya kebi- } \\
\text { jakan lain dari } \\
\text { Wali Kota }\end{array}$ & $\begin{array}{l}\text { Wali Kota } \\
\text { Depok }\end{array}$ & $\begin{array}{l}\text { Pembentukan Kampung Siaga } \\
\text { COVID-19 }\end{array}$ & $\begin{array}{l}\text { Intruksi Wali Kota Depok Nomor } \\
02 \text { Tahun } 2020\end{array}$ \\
\hline $\begin{array}{l}6 \text { April } \\
2020\end{array}$ & $\begin{array}{l}\text { Sampai terbitnya } \\
\text { kebijakan lanjut } \\
\text { dari Wali Kota }\end{array}$ & $\begin{array}{l}\text { Wali Kota } \\
\text { Depok }\end{array}$ & 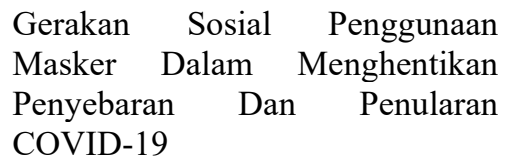 & $\begin{array}{l}\text { Surat Edaran Wali Kota Depok } \\
\text { Nomor 443/173-Huk/Dinkes Tahun } \\
2020\end{array}$ \\
\hline $\begin{array}{l}8 \text { April } \\
2020\end{array}$ & $\begin{array}{l}13 \text { April }-30 \\
\text { April } 2020\end{array}$ & $\begin{array}{l}\text { Wali Kota } \\
\text { Depok }\end{array}$ & $\begin{array}{l}\text { Perpanjangan Masa Belajar Di } \\
\text { Rumah Bagi Peserta Didik } \\
\text { PAUD/TK/RA, } \\
\text { SMP/MTS, SMA/SMK/MA Dan } \\
\text { Lembaga Pendidikan Non Formal } \\
\text { Dalam Upaya Pencegahan } \\
\text { Penyebaran COVID-19 Di Kota } \\
\text { Depok }\end{array}$ & $\begin{array}{l}\text { Surat Edaran Wali Kota Depok } \\
\text { Nomor } 420 / 177-H U K / D I S D I K \\
\text { Tahun } 2020\end{array}$ \\
\hline $\begin{array}{l}12 \text { April } \\
2020\end{array}$ & $\begin{array}{l}15 \text { April }-28 \\
\text { April } 2020\end{array}$ & $\begin{array}{l}\text { Wali Kota } \\
\text { Depok }\end{array}$ & $\begin{array}{l}\text { Pemberlakuan Pelaksanaan } \\
\text { Pembatasan Sosial Berskala Besar } \\
\text { Dalam Penanganan Corona Virus } \\
\text { Disease } 2019 \text { di Kota Depok }\end{array}$ & $\begin{array}{l}\text { Surat Keputusan Wali Kota Depok } \\
\text { No. } 443 / 177 / \text { Kpts/Dinkes/Huk/ } \\
\text { Tahun } 2020\end{array}$ \\
\hline $\begin{array}{l}12 \text { April } \\
2020\end{array}$ & $\begin{array}{l}12 \text { April }-4 \text { Mei } \\
2020\end{array}$ & $\begin{array}{l}\text { Wali Kota } \\
\text { Depok }\end{array}$ & $\begin{array}{l}\text { Pelaksanaan Pembatasan Sosial } \\
\text { Berskala Besar dalam Penanganan } \\
\text { Corona Virus Disease } 2019 \text { di Kota } \\
\text { Depok }\end{array}$ & $\begin{array}{l}\text { Peraturan Wali Kota Depok Nomor } \\
22 \text { Tahun } 2020\end{array}$ \\
\hline $\begin{array}{l}22 \text { April } \\
2020\end{array}$ & $\begin{array}{l}\text { Sampai terbit-nya } \\
\text { kebijakan lanjut } \\
\text { dari Wali Kota }\end{array}$ & $\begin{array}{l}\text { Wali Kota } \\
\text { Depok }\end{array}$ & $\begin{array}{l}\text { Peran Serta Warga masyarakat } \\
\text { dalam penanganan Corona Virus } \\
\text { Disease } 2019 \text { (COVID-19) Di } \\
\text { Kota Depok }\end{array}$ & $\begin{array}{l}\text { Surat Edaran Wali Kota Nomor } \\
\text { 460/193-Huk/GT Tahun } 2020\end{array}$ \\
\hline $\begin{array}{l}28 \text { April } \\
2020\end{array}$ & $\begin{array}{l}29 \text { April - } 12 \text { Mei } \\
2020\end{array}$ & $\begin{array}{l}\text { Wali Kota } \\
\text { Depok }\end{array}$ & $\begin{array}{l}\text { Perpanjangan Pemberlakuan } \\
\text { Pelaksanaan Pembatasan Sosial } \\
\text { Berskala Besar Dalam Penanganan } \\
\text { Corona Virus Disease } 2019 \text { di } \\
\text { Kota Depok }\end{array}$ & $\begin{array}{l}\text { Surat Keputusan Wali Kota Depok } \\
\text { Nomor } 443 / 198 / \text { Kpts/Dinkes/Huk/ } \\
\text { Tahun } 2020\end{array}$ \\
\hline $\begin{array}{l}3 \text { Mei } \\
2020\end{array}$ & $\begin{array}{l}\text { Sampai dengan } \\
\text { terbitnya } \\
\text { kebijakan lebih } \\
\text { lanjut dari Wali } \\
\text { Kota }\end{array}$ & $\begin{array}{l}\text { Wali Kota } \\
\text { Depok }\end{array}$ & $\begin{array}{l}\text { Kelengkapan Surat Tugas Bagi } \\
\text { Pegawai Yang Bekerja Pada } \\
\text { Perusahaan Kantor Yang } \\
\text { Dikecualikan Dari Penghentian } \\
\text { Aktivitas Bekerja Dalam Masa } \\
\text { Pelaksanaan PSBB Di Kota Depok }\end{array}$ & $\begin{array}{l}\text { Surat Edaran Wali Kota } \\
\text { Nomor } 443 / 224-H U K / G T \\
2020\end{array}$ \\
\hline $\begin{array}{l}4 \text { Mei } \\
2020\end{array}$ & $\begin{array}{l}\text { Sampai terdapat } \\
\text { keputusan lanjut } \\
\text { dari Wali Kota }\end{array}$ & $\begin{array}{l}\text { Wali Kota } \\
\text { Depok }\end{array}$ & $\begin{array}{l}\text { Perubahan Atas Peaturan Wali } \\
\text { Kota Nomor 22 Tahun } 2020 \\
\text { Tenatng Pelaksanaan Pembatasan } \\
\text { Sosial Berskala Besar dalam } \\
\text { Penanganan Corona Virus Disease } \\
2019 \text { di Kota Depok. }\end{array}$ & $\begin{array}{l}\text { Peaturan Wali Kota Depok Nomor } \\
32 \text { Tahun } 2020\end{array}$ \\
\hline $\begin{array}{l}12 \text { Mei } \\
2020\end{array}$ & $\begin{array}{l}13 \mathrm{Mei}-26 \mathrm{Mei} \\
2020\end{array}$ & $\begin{array}{l}\text { Wali Kota } \\
\text { Depok }\end{array}$ & $\begin{array}{l}\text { Perpanjangan Kedua } \\
\text { Pemberlakuan Pembatasan Sosial } \\
\text { Berskala Besar dalam Penanganan } \\
\text { COVID-19 di Kota Depok }\end{array}$ & $\begin{array}{l}\text { Surat Keputusan Wali Kota Depok } \\
\text { No.443/206/Kpts/Dinkes/Huk/2020 }\end{array}$ \\
\hline $\begin{array}{l}26 \text { Mei } \\
2020\end{array}$ & $\begin{array}{l}26 \text { Mei - } 29 \text { Mei } \\
2020\end{array}$ & $\begin{array}{l}\text { Wali Kota } \\
\text { Depok }\end{array}$ & $\begin{array}{l}\text { Perpanjangan PSBB dalam rangka } \\
\text { Percepatan } \\
\text { COVID-19 }\end{array}$ & $\begin{array}{l}\text { Surat Keputusan Wali Kota Depok } \\
\text { No.443/217/Kpts/Dinkes/Huk/2020 }\end{array}$ \\
\hline
\end{tabular}




\begin{tabular}{|c|c|c|c|c|}
\hline $\begin{array}{c}\text { Tanggal } \\
\text { Terbit }\end{array}$ & Masa Berlaku & $\begin{array}{l}\text { Lembaga } \\
\text { Penerbit }\end{array}$ & Judul Kebijakan & Referensi \\
\hline $\begin{array}{c}29 \text { Mei } \\
2020\end{array}$ & $\begin{array}{l}29 \text { Mei - } 4 \text { Juni } \\
2020\end{array}$ & $\begin{array}{l}\text { Wali Kota } \\
\text { Depok }\end{array}$ & $\begin{array}{lrr}\text { Perpanjangan } & \text { Keempat } \\
\text { Pelaksanaan } & \text { PSBB } & \text { Dalam } \\
\text { Penanganan COVID-19 } & \text { di Kota } \\
\text { Depok } & & \end{array}$ & $\begin{array}{l}\text { Surat Keputusan Wali Kota Depok } \\
\text { No.443/230/Kpts/DPKP/Huk/2020 }\end{array}$ \\
\hline $\begin{array}{l}29 \text { Mei } \\
2020\end{array}$ & $\begin{array}{l}30 \text { Mei - } 4 \text { Juni } \\
2020\end{array}$ & $\begin{array}{l}\text { Wali Kota } \\
\text { Depok }\end{array}$ & $\begin{array}{l}\text { Perpanjangan Masa Penyesuaian } \\
\text { Sistem Kerja ASN Dan Pegawai } \\
\text { Non ASN Di Lingkungan } \\
\text { Pemerintah Daerah Kota Depok }\end{array}$ & $\begin{array}{l}\text { Surat Edaran Wali Kota Depok } \\
\text { Nomor } 800 / 257-H U K / B K P S D M \\
\text { Tahun } 2020\end{array}$ \\
\hline $\begin{array}{l}29 \text { Mei } \\
2020\end{array}$ & $\begin{array}{l}30 \text { Mei - } 30 \text { Juni } \\
2020\end{array}$ & $\begin{array}{l}\text { Wali Kota } \\
\text { Depok }\end{array}$ & $\begin{array}{l}\text { Penetapan Perpanjagan Status } \\
\text { Tanggap Darurat Bencana Corona } \\
\text { Virus Disease 2019 Di Kota Depok }\end{array}$ & $\begin{array}{l}\text { Surat Keputusan Wali Kota Depok } \\
\text { No.443/230/Kpts/Dinkes/Huk/2020 }\end{array}$ \\
\hline $\begin{array}{l}4 \text { Juni } \\
2020\end{array}$ & $\begin{array}{l}5 \text { Juni }-2 \text { Juli } \\
2020\end{array}$ & $\begin{array}{l}\text { Wali Kota } \\
\text { Depok }\end{array}$ & 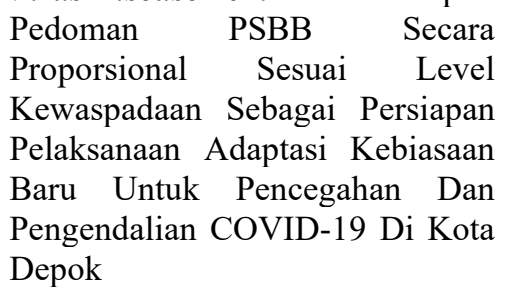 & $\begin{array}{l}\text { Peraturan Wali Kota Depok Nomor } \\
37 \text { Tahun } 2020\end{array}$ \\
\hline $\begin{array}{c}4 \text { juni } \\
2020\end{array}$ & $\begin{array}{l}5 \text { Juni }-18 \text { Juni } \\
2020\end{array}$ & $\begin{array}{l}\text { Wali Kota } \\
\text { Depok }\end{array}$ & $\begin{array}{l}\text { Penetapan Wilayah Pembatasan } \\
\text { Sosial Kampung Siaga COVID-19 }\end{array}$ & $\begin{array}{l}\text { Surat Keputusan Wali Kota Depok } \\
\text { Nomor } 443 / 235 / \text { Ktps/Dinkes/Huk } \\
\text { Tahun } 2020\end{array}$ \\
\hline $\begin{array}{c}6 \text { Juni } \\
2020\end{array}$ & $\begin{array}{l}\text { Sampai dengan } \\
\text { terbitnya } \\
\text { kebijakan lebih } \\
\text { lanjut dari Ketua } \\
\text { Gugus }\end{array}$ & $\begin{array}{l}\text { Ketua Gugus } \\
\text { Tugas } \\
\text { Percepatan } \\
\text { Penanganan } \\
\text { COVID-19 }\end{array}$ & $\begin{array}{l}\text { Kriteria dan Persyaratan } \\
\text { Perjalanan Orang Dalam Masa } \\
\text { Adaptasi Kebiasaan Baru Menuju } \\
\text { Masyarakat Produktif Dan Aman } \\
\text { COVID-19 }\end{array}$ & 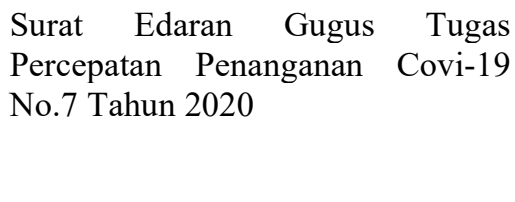 \\
\hline
\end{tabular}

Tabel 2. Analisis Segitiga Kebijakan

\begin{tabular}{|c|c|c|c|c|c|}
\hline $\begin{array}{c}\text { No } \\
1 \mathrm{a}\end{array}$ & Peraturan Pemerintah & \multicolumn{2}{|c|}{ Aktor Kebijakan } & Konteks & Isi \\
\hline $1 \mathrm{a}$ & $\begin{array}{l}\text { Surat Edaran Wali Kota } \\
\text { Depok No. 443/132- } \\
\text { Huk/Dinkes Tahun 2020 } \\
\text { tentang Tindak Lanjut } \\
\text { Pencegahan Penyebaran } \\
\text { COVID-19 di Kota Depok }\end{array}$ & $\begin{array}{c}\text { Wali } \\
\text { Kota } \\
\text { Depok }\end{array}$ & $\begin{array}{l}\text { 1. Kepala Perangkat } \\
\text { Daerah di Kota } \\
\text { Depok } \\
\text { 2. Camat dan Lurah } \\
\text { di Kota Depok } \\
\text { 3. Ketua RW dan RT } \\
\text { se-Kota Depok } \\
\text { 4. Seluruh } \\
\text { Masyarakat Kota } \\
\text { Depok }\end{array}$ & $\begin{array}{l}\text { Sosial, } \\
\text { Pendidikan } \\
\text { dan Kesehatan }\end{array}$ & $\begin{array}{l}\text { 1. Seluruh satuan pendidikan di } \\
\text { Kota Depok agar meliburkan } \\
\text { pelaksanaan kegiatan belajar } \\
\text { dan menunda pelaksanaan } \\
\text { outing class/study tour. } \\
\text { 2. Pelaksanaan posyandu dan } \\
\text { posbindu dihentikan semen- } \\
\text { tara, untuk pelayanan imun- } \\
\text { isasi dan pemeriksaan ibu hal } \\
\text { dilaksa-nakan di Puskesmas. } \\
\text { Dinas perhubungan me- } \\
\text { niadakan sementara kegiatan } \\
\text { car free day } \\
\text { Dinas lingkungan hidup dan } \\
\text { kebersihan menutup sementara } \\
\text { Alun-Alun Kota Depok } \\
\text { Disporyata menunda per- } \\
\text { tandingan di stadion olah-raga } \\
\text { Seluruh perangkat daerah agar } \\
\text { Menunda kegiatan kunjungan } \\
\text { kerja dan penerimaan } \\
\text { kunjungan kerja. } \\
\text { Seluruh pemilik/pengelola } \\
\text { perkantoran, pusat perbe- } \\
\text { lanjaan, pasar tradisional, } \\
\text { hotel, tempat hiburan, restoran, } \\
\text { tempat wisata, tempat ibadah } \\
\text { dan tempat umum lainnya agar } \\
\text { menyediakan sarana cuci }\end{array}$ \\
\hline
\end{tabular}




\begin{tabular}{|c|c|c|c|c|c|}
\hline \multirow{2}{*}{ No } & \multirow{2}{*}{ Peraturan Pemerintah } & \multicolumn{2}{|c|}{ Aktor Kebijakan } & \multirow{2}{*}{ Konteks } & \multirow{2}{*}{ Isi } \\
\hline & & Pembuat & Ditujukan kepada & & \\
\hline & & & & & $\begin{array}{l}\text { tangan berupa air mengalir dan } \\
\text { sabun antiseptic/hand sanitizer } \\
\text { 8. Seluruh warga masyarakat } \\
\text { agar Menghindari kontak fisik, } \\
\text { menghindari tempat umum/ } \\
\text { keramaian/ruang publik apa- } \\
\text { bila tidak ada kepentingan } \\
\text { mendesak, menjaga kesehatan } \\
\text { dengan membiasakan perilaku } \\
\text { hidup bersih dan sehat } \\
\text { (PHBS). }\end{array}$ \\
\hline
\end{tabular}

Depok No. 420/142-

HUK/DISDIK Tahun 2020

tentang Perpanjangan Masa

Belajar Di Rumah Bagi

Peserta Didik

PAUD/TK/RA, SD/MI,

SMP/MTS,

SMA/SMK/MA Dan

Lembaga Pendidikan Non

Formal Dalam Upaya

Pencegahan Penyebaran

COVID-19 Di Kota Depok

1c Surat Edaran Wali Kota Depok No. 420/177HUK/DISDIK Tahun 2020 tentang Perpanjangan Masa Belajar Di Rumah Bagi Peserta Didik PAUD/TK/RA, SD/MI, SMP/MTS,

SMA/SMK/MA Dan

Lembaga Pendidikan Non

Formal Dalam Upaya Pencegahan Penyebaran COVID-19 Di Kota Depok
Kota

Depok

\section{PAUD/TK/RA di}

Kota Depok

2. Kepala Sekolah SD/MI di Kota Depok

3. Kepala Sekolah SMP/MTs di Kota Depok

4. Kepala Sekolah SMA/SMK/MA

di Kota Depok

Wali

Kota

Depok

1. Kepala Sekolah PAUD/TK/RA di Kota Depok

2. Kepala Sekolah SD/MI di Kota Depok

3. Kepala Sekolah SMP/MTs di Kota Depok

4. Kepala Sekolah SMA/SMK/MA di Kota Depok

5. Kepala Lembaga Pendidikan Non Formal di Kota Depok

\begin{tabular}{|c|c|c|c|c|c|c|}
\hline 2 & $\begin{array}{l}\text { Surat Keputusan Wali Kota } \\
\text { Depok No. 360/137/Kpts/ } \\
\text { DPKP/Huk/2020 Tahun } \\
2020 \text { tentang Penetapan } \\
\text { Status Tanggap Darurat } \\
\text { Bencana COVID-19 di } \\
\text { Kota Depok }\end{array}$ & $\begin{array}{c}\text { Wali } \\
\text { Kota } \\
\text { Depok }\end{array}$ & - & $\begin{array}{l}\text { Sosial, } \\
\text { Kesehatan, } \\
\text { Ekonomi }\end{array}$ & $\begin{array}{l}3 . \\
4 .\end{array}$ & $\begin{array}{l}\text { Menetapkan status tanggap } \\
\text { darurat bencana COVID-19 di } \\
\text { Kota Depok } \\
\text { Menunjuk ketua gugus tugas } \\
\text { percepatan penanganan ben- } \\
\text { cana, kepala dinas pemadam } \\
\text { kebakaran dan penyelamatan, } \\
\text { kepala dinas kesehatan } \\
\text { COVID-19 di Kota Depok } \\
\text { Menetapkan segala biaya } \\
\text { dibebankan pada APBD Kota } \\
\text { Depok unat } \\
\text { Menghimbau seluruh umat } \\
\text { beragama di Kota Depok } \\
\text { untuk tidak melaksanakan } \\
\text { ibadah di tempat ibadah } \\
\text { termasuk perayaan atau } \\
\text { kegiatan keagamaan yang } \\
\text { melibatkan banya orang. }\end{array}$ \\
\hline
\end{tabular}




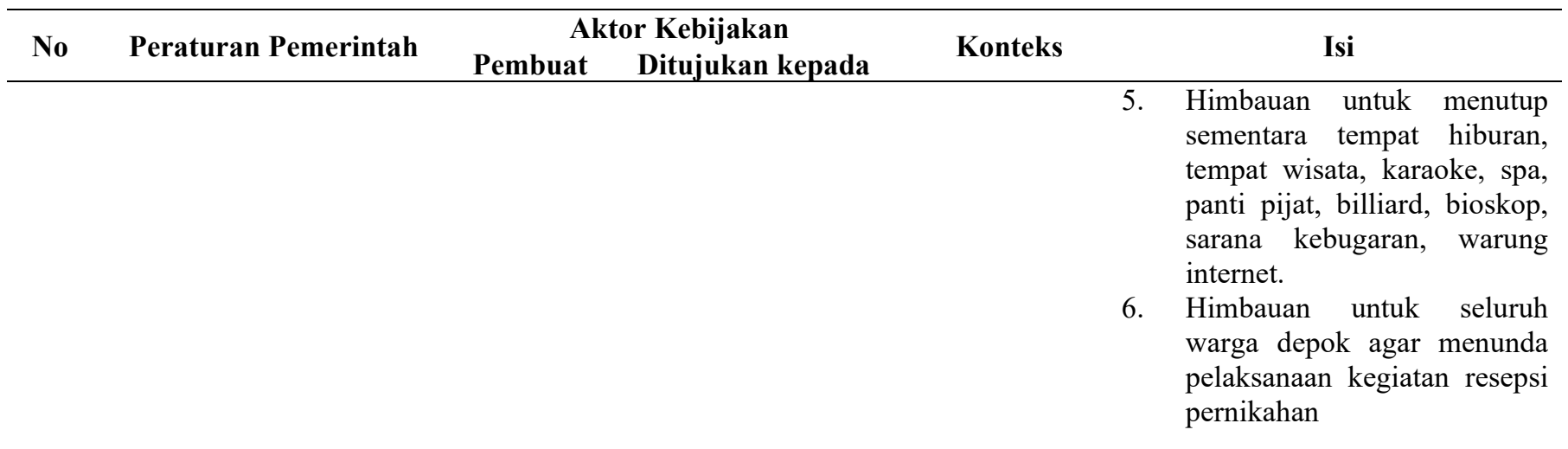

\begin{tabular}{|c|c|}
\hline \multirow[t]{9}{*}{$3 a$} & Surat Edaran Wali Kota \\
\hline & Depok No. 800/141- \\
\hline & Huk/BKPSDM Tahun 2020 \\
\hline & tentang Penyesuaian Sistem \\
\hline & Kerja Aparatur Sipil Negara \\
\hline & Dalam Upaya Pencegahan \\
\hline & Penyebaran COVID-19 Di \\
\hline & Lingkungan Pemerintah \\
\hline & Daerah Kota Depok \\
\hline \multirow[t]{11}{*}{$3 b$} & Surat Edaran Wali Kota \\
\hline & Depok No. 800/155- \\
\hline & Huk/BKPSDM Tahun 2020 \\
\hline & tentang Perpanjangan Masa \\
\hline & Penyesuaian Sistem Kerja \\
\hline & ASN Dan Pegawai Non \\
\hline & ASN Dalam Upaya \\
\hline & Pencegahan Penyebaran \\
\hline & COVID-19 Di Lingkungan \\
\hline & Pemerintah Daerah Kota \\
\hline & Depok \\
\hline \multirow[t]{8}{*}{$3 c$} & Surat Edaran Wali Kota \\
\hline & Depok No. 800/257- \\
\hline & HUK/BKPSDM \\
\hline & 2020 tentang Perpanjangan \\
\hline & Masa Penyesuaian Sistem \\
\hline & Kerja ASN Dan Pegawai \\
\hline & Non ASN Di Lingkungan \\
\hline & $\begin{array}{l}\text { Pemerintah Daerah Kota } \\
\text { Depok }\end{array}$ \\
\hline
\end{tabular}

4 Surat Edaran Wali Kota Depok No. 560/152Disnaker Tahun 2020 tentang Himbauan Pelaksanaan Bekerja Dari Rumah (WFH) Untuk Kegiatan Perkantoran, Perusahaan/Pelaku Usaha Dan Pemilik Usaha Dalam Rangka Mencegah Penyebaran COVID-19

\begin{tabular}{|c|c|c|c|}
\hline Wali & 1. & Kepala Perangkat & Pemerintahan \\
\hline Kota & & Daerah di Kota & \\
\hline Depok & & Depok & \\
\hline & 2. & Seluruh ASN dan & \\
\hline & & Pegawai Non & \\
\hline & & ASN di Kota & \\
\hline & & Depok & \\
\hline Wali & 1. & Kepala Perangkat & Pemerintahan \\
\hline Kota & & Daerah di Kota & \\
\hline Depok & & Depok & \\
\hline & 2. & Seluruh ASN dan & \\
\hline & & Pegawai Non & \\
\hline & & ASN di Kota & \\
\hline & & Depok & \\
\hline
\end{tabular}

Wali 1. Kepala Perangkat Pemerintahan

Kota Daerah di Kota

Depok Depok

2. Seluruh ASN dan Pegawai Non ASN di Kota Depok
Menetapkan WHF kepada seluruh ASN dan Non ASN kecuali perangkat daerah yang melaksanakan pelayanan langsung kepada masyarakat agar tetap memberikan pelayanan kepada masyarakat dengan mengatur sistem kerja yang akuntabel da selektif melalui pembagian kehadiran.

Menetapkan $W F H$ kepada seluruh ASN dan Non ASN kecuali perangkat daerah yang melaksanakan pelayanan langsung kepada masyarakat agar tetap memberikan pelayanan kepada masyarakat dengan mengatur sistem kerja yang akuntabel da selektif melalui pembagian kehadiran.

Menetapkan $W H F$ kepada seluruh ASN dan Non ASN kecuali perangkat daerah yang melaksanakan pelayanan langsung kepada masyarakat agar tetap memberikan pelayanan kepada masyarakat dengan mengatur sistem kerja yang akuntabel da selektif melalui pembagian kehadiran.

$\begin{array}{clll}\text { Wali } & \text { Pimpinan } & \text { Sosial dan } \\ \text { Kota } & \text { Perkantoran, } & \text { Ekonomi } & \\ \text { Depok } & \text { Perusahaan/ Pelaku } & \\ & \text { Usaha/Pemilik Usaha } & & \end{array}$
Menghimbau seluruh perkantoran, perusahaan, dan usaha Mengambil langkahlangkah pencegahan terkait resiko penularan COVID-19, menghentikan sementara seluruh kegiatan dan diganti dengan melakukan kegiata bekerja di rumah kecuali perusahan yang berkaitan dengan pelayanan kesehatan, penyediaan kebutuhan bahan pokok dan bahan bakar minyak.

2. Mengatur batas jumlah karyawan, waktu kegiatan dan fasilitias operasional bagi perkantoran, perusahaan, dan 


\begin{tabular}{|c|c|c|c|c|c|}
\hline \multirow{3}{*}{ No } & \multirow{2}{*}{ Peraturan Pemerintah } & \multicolumn{2}{|c|}{ Aktor Kebijakan } & \multirow{2}{*}{ Konteks } & \multirow{2}{*}{ Isi } \\
\hline & & Pembuat & Ditujukan kepada & & \\
\hline & & & & & $\begin{array}{l}\text { usaha yang tidak dapat } \\
\text { menyelenggarakan WFH. }\end{array}$ \\
\hline 5 & $\begin{array}{l}\text { Instruksi Wali Kota Depok } \\
\text { No. 02 Tahun } 2020 \text { tentang } \\
\text { Pembentukan Kampung } \\
\text { Siaga COVID-19 }\end{array}$ & $\begin{array}{l}\text { Wali } \\
\text { Kota } \\
\text { Depok }\end{array}$ & - & $\begin{array}{l}\text { Sosial dan } \\
\text { Kesehatan }\end{array}$ & $\begin{array}{l}\text { Membentuk dan menyeleng- } \\
\text { garakan kampung siaga COVID- } \\
19 \text { berbasis RW di seluruh RW di } \\
\text { Kota Depok. }\end{array}$ \\
\hline 6 & $\begin{array}{l}\text { Surat Edaran Wali Kota } \\
\text { Depok No. 443/173- } \\
\text { Huk/Dinkes Tahun 2020 } \\
\text { tentang Gerakan Sosial } \\
\text { Penggunaan Masker Dalam } \\
\text { Menghentikan Penyebaran } \\
\text { Dan Penularan COVID-19 }\end{array}$ & $\begin{array}{c}\text { Wali } \\
\text { Kota } \\
\text { Depok }\end{array}$ & $\begin{array}{l}\text { 1. Seluruh Masyarakat } \\
\text { Kota Depok }\end{array}$ & $\begin{array}{l}\text { Sosial dan } \\
\text { Kesehatan }\end{array}$ & $\begin{array}{l}\text { Menghimbau seluruh masyarakat } \\
\text { Kota Depok agar selalu } \\
\text { menggunakan masker ketika } \\
\text { terpaksa harus beraktifitas di luar } \\
\text { rumah terutama menggunaka } \\
\text { masker kain dengan dua lapisan } \\
\text { kain yang dapat dicuci. }\end{array}$ \\
\hline $7 \mathrm{a}$ & $\begin{array}{l}\text { Surat Keputusan Wali Kota } \\
\text { Depok No. } \\
443 / 177 / \text { Kpts/Dinkes/Huk/ } \\
\text { Tahun 2020 tentang } \\
\text { Pemberlakuan Pelaksanaan } \\
\text { Pembatasan Sosial Berskala } \\
\text { Besar Dalam Penanganan } \\
\text { COVID-19 di Kota Depok }\end{array}$ & $\begin{array}{l}\text { Wali } \\
\text { Kota } \\
\text { Depok }\end{array}$ & - & Sosial & $\begin{array}{l}\text { 1. Memberlakukan pelaksanaan } \\
\text { pembatasan sosial berskala } \\
\text { besar dalam penanganan } \\
\text { COVID-19 di Kota Depok } \\
\text { 2. Menghimbau seluruh } \\
\text { masyarakat Kota Depok } \\
\text { mematuhi dan secara } \\
\text { konsisten menerapkan } \\
\text { protokol kesehatan } \\
\text { pencegahan COVID-19. }\end{array}$ \\
\hline $7 b$ & $\begin{array}{l}\text { Surat Keputusan Wali Kota } \\
\text { Depok } \\
\text { No.443/198/Kpts/Dinkes/H } \\
\text { uk/ Tahun } 2020 \text { tentang } \\
\text { Perpanjangan } \\
\text { Pemberlakuan Pelaksanaan } \\
\text { PSBB Dalam Penanganan } \\
\text { COVID-19 di Kota Depok }\end{array}$ & $\begin{array}{l}\text { Wali } \\
\text { Kota } \\
\text { Depok }\end{array}$ & - & Sosial & $\begin{array}{l}\text { 1. Memberlakukan } \\
\text { perpanjangan pelaksanaan } \\
\text { pembatasan sosial berskala } \\
\text { besar dalam penanganan } \\
\text { COVID-19 di Kota Depok } \\
\text { 2. } \text { Menghimbau seluruh } \\
\text { masyarakat Kota Depok } \\
\text { mematuhi dan secara } \\
\text { konsisten menerapkan } \\
\text { protokol kesehatan } \\
\text { pencegahan COVID-19 }\end{array}$ \\
\hline $7 \mathrm{c}$ & $\begin{array}{l}\text { Surat Keputusan Wali Kota } \\
\text { Depok No. } \\
443 / 206 / \text { Kpts/Dinkes/Huk/ } \\
\text { Tahun 2020 tentang } \\
\text { Perpanjangan Kedua } \\
\text { Pemberlakuan PSBB dalam } \\
\text { Penanganan COVID-19 di } \\
\text { Kota Depok }\end{array}$ & $\begin{array}{l}\text { Wali } \\
\text { Kota } \\
\text { Depok }\end{array}$ & - & Sosial & $\begin{array}{l}\text { 1. Memberlakukan pelaksanaan } \\
\text { pembatasan sosial berskala } \\
\text { besar dalam penanganan } \\
\text { COVID-19 di Kota Depok } \\
\text { 2. Menghimbau seluruh } \\
\text { masyarakat Kota Depok } \\
\text { mematuhi dan secara } \\
\text { konsisten menerapkan } \\
\text { protokol kesehatan } \\
\text { pencegahan COVID-19 }\end{array}$ \\
\hline $7 d$ & 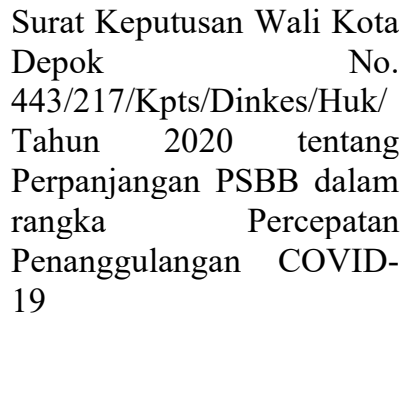 & $\begin{array}{l}\text { Wali } \\
\text { Kota } \\
\text { Depok }\end{array}$ & - & Sosial & 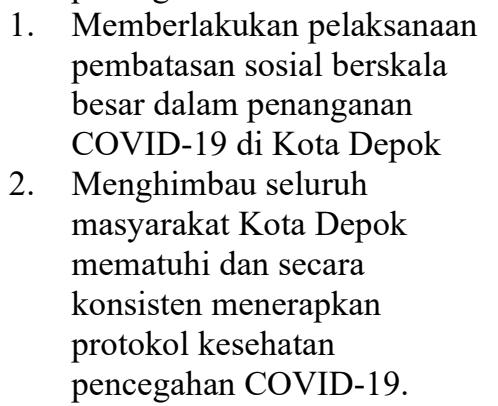 \\
\hline $7 \mathrm{e}$ & 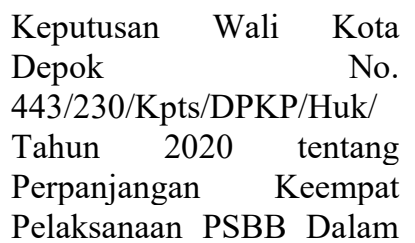 & $\begin{array}{l}\text { Wali } \\
\text { Kota } \\
\text { Depok }\end{array}$ & - & Sosial & $\begin{array}{l}\text { 1. Memberlakukan pelaksanaan } \\
\text { pembatasan sosial berskala } \\
\text { besar dalam penanganan } \\
\text { corona virus disease } 2019 \\
\text { (COVID-19) di Kota Depok }\end{array}$ \\
\hline
\end{tabular}




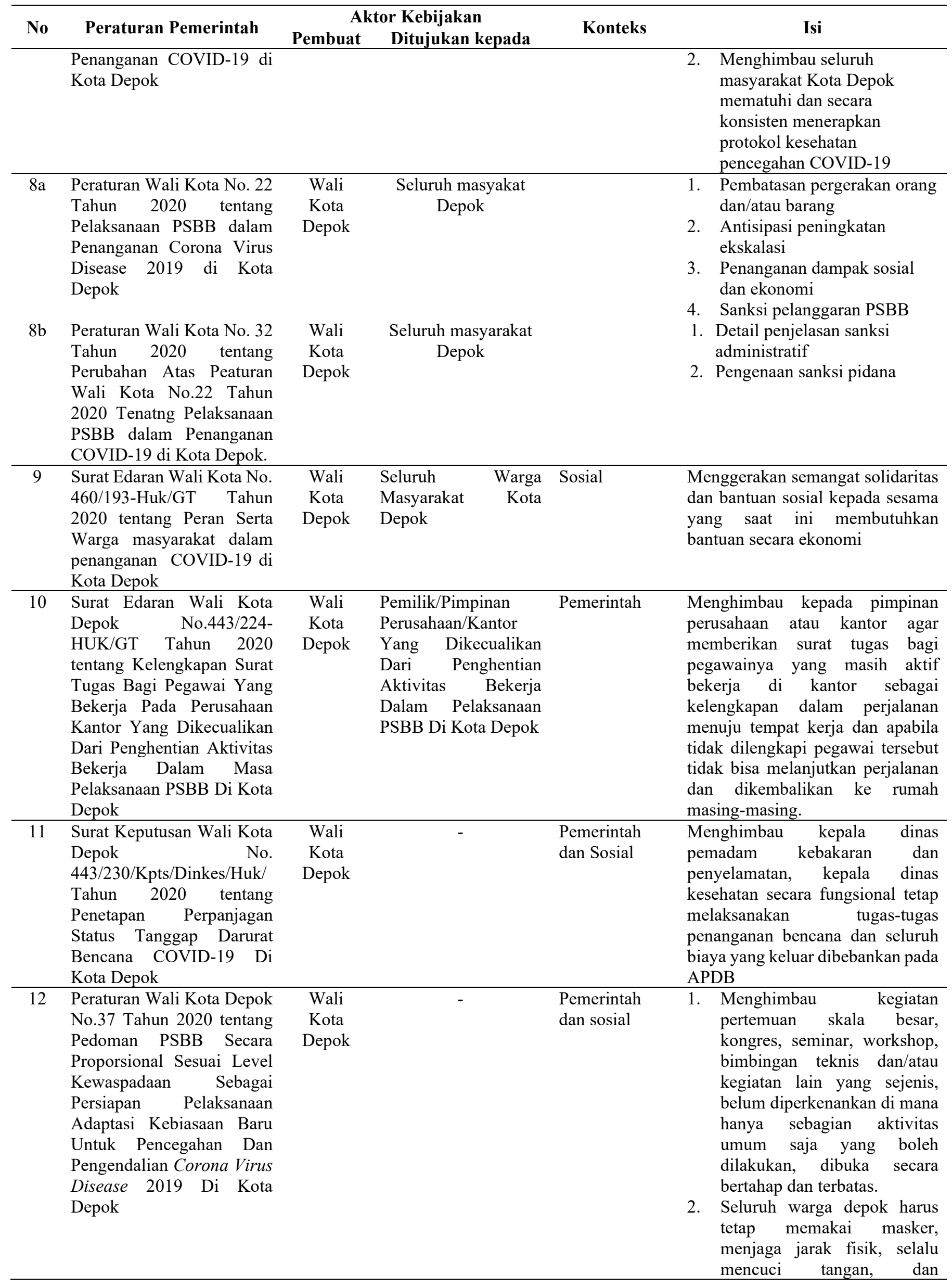




\begin{tabular}{|c|c|c|c|c|c|}
\hline \multirow[t]{2}{*}{ No } & Peraturan Pemerintah & \multicolumn{2}{|c|}{ Aktor Kebijakan } & Konteks & Isi \\
\hline & & & & & $\begin{array}{l}\text { membudayakan kembali pola } \\
\text { hidup bersih dan sehat }\end{array}$ \\
\hline 13 & \begin{tabular}{lr}
\multicolumn{3}{l}{ Surat Keputusan Wali Kota } \\
Depok & No. \\
$443 / 235 / K t p s / D i n k e s / H u k$ \\
Tahun 2020 & tentang \\
Penetapan & Wilayah \\
Pembatasan & Sosial \\
Kampung Siaga COVID-19
\end{tabular} & $\begin{array}{c}\text { Wali } \\
\text { Kota } \\
\text { Depok }\end{array}$ & - & $\begin{array}{l}\text { Sosial dan } \\
\text { Kesehatan }\end{array}$ & 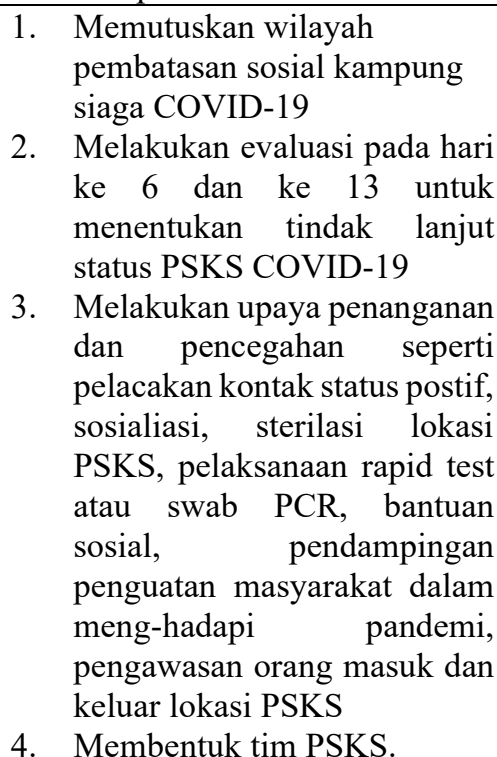 \\
\hline 14 & 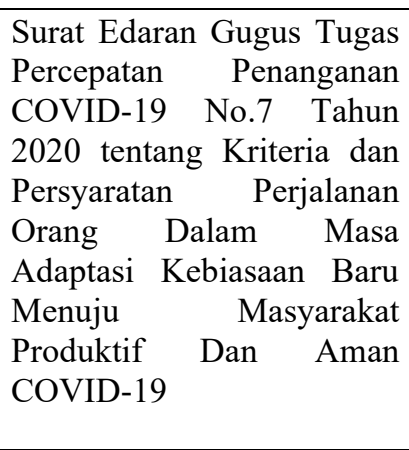 & $\begin{array}{c}\text { Ketua } \\
\text { Gugus } \\
\text { Tugas } \\
\text { Percepata } \\
\text { n } \\
\text { Penangan } \\
\text { an Virus } \\
\text { Disease } \\
2019 \\
\text { (COVID- } \\
\text { 19) }\end{array}$ & - & $\begin{array}{l}\text { Sosial dan } \\
\text { Kesehatan }\end{array}$ & $\begin{array}{l}\text { Menentukan kriteria dan } \\
\text { persyaratan perjalanan orang } \\
\text { dalam masa adaptasi kebiasaan } \\
\text { baru menuju kehidupan produktif } \\
\text { dan aman corona virus disease } \\
2019 \text { (COVID-19) diantaranya } \\
\text { individu yang melaksananan } \\
\text { perjalanan wajib menerapkan dan } \\
\text { mematuhi protokol baik perjalanan } \\
\text { dalam negeri dan luar negeri. }\end{array}$ \\
\hline
\end{tabular}

\section{PEMBAHASAN}

\section{Pembatasan Sosial Berskala Besar (PSBB)}

PSBB adalah pembatasan kegiatan tertentu penduduk dalam suatu wilayah yang diduga terinfeksi COVID-19 untuk mencegah kemungkinan penyebarannya. Kebijakan PSBB ditetapkan oleh pemerintah apabila jumlah kasus dan/atau jumlah kematian meningkat dan menyebar secara signifikan ke beberapa wilayah, dan terdapat kaitan epidemiologi dengan kejadian serupa di wilayah atau negara lain. ${ }^{15}$ Dalam penetapan PSBB di suatu wilayah, maka Gubernur/ Bupati/ Wali Kota yang mengajukan permohonan PSBB kepada Menteri Kesehatan wajib menyertakan data peningkatan jumlah kasus menurut waktu, penyebaran kasus menurut waktu, dan kejadian transmisi lokal disertai dengan kurva epidemiologi. ${ }^{16}$

Angka Reproduksi Efektif (Rt) merupakan parameter yang digunakan untuk menindaklanjuti epidemi ${ }^{49}$ dan dianggap sebagai nilai statistik untuk memgukur keberhasilan PSBB. ${ }^{35}$ Sesuai Internation Journal "Clinical, laboratory and imaging features of COVID19: A systematic review and meta-analysis" (2020) dimana negara-negara Amerika Latin memiliki Rt $>2$, menunjukkan adanya pertumbuhan eksponensial. Hal ini berarti terdapat kemungkinan besar kapasitas sistem perawatan Amerika Latin sudah kewalahan dan berdampak serius di kawasan tersebut. Mengingat konteks negara yang terpecah secara politik, ketidaksetaraan sosial, keterba-

Tabel 3. Analisis Strategi dengan Pendekatan SWOT

\begin{tabular}{|c|c|c|}
\hline & S & W \\
\hline
\end{tabular}




\begin{tabular}{|c|c|c|}
\hline Aspek Eksternal & $\begin{array}{l}\text { 1. Adanya kebijakan PSBB yang } \\
\text { komprehensif. } \\
\text { 2. Kebijakan PSBB terpusat dan } \\
\text { melibatkan kolaborasi multisektor } \\
\text { 3. Adanya aturan jelas secara teknis dan } \\
\text { administratif termasuk sanksi PSBB. } \\
\text { 4. Bantuan dana sosial melalui JPS. } \\
\text { 5. Penetapan Kampung Siaga (PSKS) } \\
\text { tingkat RW. } \\
\text { 6. Protokol adanya CTPS dan } \\
\text { pelaksanaan check point } \\
\text { 7. Evidence based terlapor melalui } \\
\text { CCC. }\end{array}$ & $\begin{array}{l}\text { 1. Implementasi kebijakan PSBB } \\
\text { belum merata. } \\
\text { 2. Kurangnya reward bagi sinergi } \\
\text { masyarakat. } \\
\text { 3. Kurangnya koordinasi dengan } \\
\text { perangkat di tingkat RT/RW } \\
\text { terkait bantuan dana sosial. } \\
\text { 4. Kurang konsistennya } \\
\text { pemberlakuan sanksi terhadap } \\
\text { masyarakat. } \\
\text { 5. Kurang transparannya aturan atau } \\
\text { data yang dirilis pemerintah. } \\
\text { 6. Lemahnya sistem Pendidikan PJJ. }\end{array}$ \\
\hline $\mathbf{O}$ & SO & WO \\
\hline $\begin{array}{l}\text { 1. Munculnya kebijakan nasional } \\
\text { dan sektoral yang mengatur } \\
\text { PSBB di Kota Depok. } \\
\text { 2. Perbaikan dan inspeksi lebih } \\
\text { lanjut untuk sistem darurat } \\
\text { Kesehatan. } \\
\text { 3. Adaptasi e-Learning system } \\
\text { 4. Masyarakat Kampung Siaga } \\
\text { dapat berupaya mandiri } \\
\text { membatu pelaksanaan } \\
\text { kebijakan. } \\
\text { 5. Adaptasi membiasakan pola } \\
\text { perilaku PHBS. }\end{array}$ & $\begin{array}{l}\text { 1. Pembentukan SATGAS Jabodetabek } \\
\text { 2. Kolaborasi multisektoral, masyarakat } \\
\text { sipil dan masyarakat umum. } \\
\text { 3. Konsistensi dan eksistensi yang } \\
\text { berorientasi pada pelaksanaan } \\
\text { pemberdayaan masyarakat. } \\
\text { 4. Pengawasan kualitas penerapan } \\
\text { sistem pendidikan. }\end{array}$ & $\begin{array}{l}\text { 1. Departemen darurat kesehatan di } \\
\text { Perguruan Tinggi, dan } \\
\text { departemen manajemen darurat } \\
\text { kesehatan di semua institusi. } \\
\text { 2. Evaluasi kerja tim pelaksana } \\
\text { pengawasan dan pemantauan } \\
\text { kebijakan. } \\
\text { 3. Optimalkan tracing yang agresif, } \\
\text { isolasi dan treatment mandiri yang } \\
\text { disiplin pada masyarakat untuk } \\
\text { sigap kesehatan. } \\
\text { 4. Laporan dan evaluasi terhadap } \\
\text { pemberlakuan sanksi. } \\
\text { 5. Informasi transparan terhadap } \\
\text { perubahan kebijakan/aturan yang } \\
\text { terkait. } \\
\text { 6. Evaluasi efektifitas sistem } \\
\text { pembelajaran PJJ. }\end{array}$ \\
\hline $\mathbf{T}$ & ST & WT \\
\hline $\begin{array}{l}\text { 1. Dampak Ekonomi mengancam } \\
\text { sektor informal dan masyarakat } \\
\text { berpenghasilan rendah. } \\
\text { 2. Dampak psikologis dan sosial } \\
\text { masyarakat. } \\
\text { 3. Potensi tindak kriminalitas. } \\
\text { 4. Upaya sistem pendidikan yang } \\
\text { tidak merata dan inefektif. }\end{array}$ & $\begin{array}{l}\text { 1. Perkuat intervensi publik dalam } \\
\text { menanggapi keadaan darurat. } \\
\text { 2. Mengembangkan fungsi sistem media } \\
\text { dan kesehatan. } \\
\text { 3. Monitoring keamanan daerah dan } \\
\text { evaluasi pemerataan bantuan dana. }\end{array}$ & $\begin{array}{l}\text { 1. Perketat sanksi untuk } \\
\text { meningkatkan kepatuhan warga. } \\
\text { 2. Koordinasikan untuk } \\
\text { memaksimalkan implementasi } \\
\text { yang masih kurang dan belum } \\
\text { optimal. } \\
\text { 3.Perkuat riset dan transparansi } \\
\text { mengenai COVID -19. } \\
\text { 4. Perkuat intervensi psikologis } \\
\text { publik dalam menanggapi } \\
\text { keadaan darurat kesehatan } \\
\text { masyarakat. } \\
\text { 5. Optimalkan kualitas PJJ Tim } \\
\text { Pengajar (Kurikulum Pendidikan } \\
\text { Darurat) } \\
\text { 6. Koordinasikan laporan tertulis } \\
\text { evaluasi penyerahan bantuan } \\
\text { dana. }\end{array}$ \\
\hline
\end{tabular}

Keterangan: SO: Strength-opportunity, WO: Weakness-Opportunity, ST: Strenght-Threat, WT: Weakness-Threat 
tasan ekonomi, konflik internal, dan protes sosial. ${ }^{45,46,54}$ Studi Muhammad Fajar dari BPS (Badan Pusat Statistik) ${ }^{36}$ mengatakan apabila angka Rt di Indonesia $>1$ mengindentifikasikan hanya khusus terkait jumlah kasus yang meningkat, sebaliknya bila nilai $\mathrm{Rt}<1$ mengindentifikasikan penurunan jumlah kasus.

Rt dihitung sebagai alat untuk melihat perkembangan antar waktu dan merupakan jumlah rata-rata aktual kasus sekunder per kasus primer. ${ }^{46,54}$ Angka Rt Kota Depok pada tanggal 25 Mei 2020 adalah 1,39. Hal ini mendukung bagi pelaksanaan perpanjangan PSBB di Kota Depok. ${ }^{36}$

\section{Analisis Konten (Content Analysis)}

Secara nasional data menunjukkan $70 \%$ persebaran COVID-19 ada di wilayah Jabodetabek. ${ }^{40}$ Kepercayaan untuk menangani permasalahan global menuntut semua kerja aktif pemengang kepentingan. Di Filipina, melalui prosedur pelaksanaan ECQ (Echanced community quarantine) terlihat bahwa pemerintah pusat memberikan peran lebih banyak kepada pemerintah daerah atau yang disebut LGU (Local Goverment Units) menindaklanjuti dengan mengeluarkan ordinance (semacam Peraturan Daerah). ${ }^{48}$ Di Indonesia sendiripun dikenal dengan Surat Keputusan/ Surat Edaran yang langsung diturunkan oleh Pemerintah Daerah.

Menurut United Nations untuk mengukur tata kelola pemerintahan yang baik dibutuhkan akuntabilitas dan transparansi yang dianggap sebagai faktor yang paling berpengaruh dalam pemerintahan daerah. ${ }^{50}$ Salah satu akuntabilitas Pemkot adalah membentuk Satuan Gugus Tugas Percepatan Penanganan COVID-19 di Kota Depok. Tugas Satuan ini untuk menyusun beberapa kajian PSBB yang terdiri dari kajian epidemologi kesiapan daerah, aspek ketersediaan kebutuhan hidup dasar rakyat, sarana prasarana kesehatan, anggaran, operasional Jaring Pengaman Sosial (JPS) dan aspek keamanan yang diatur dalam Surat Edaran No.443/172/Huk/Disperindag tentang Pengaturan kegiatan usaha ritel, grosir atau eceran, supermarket, minimarket, dan toko swalayan $^{38}$ serta Surat Edaran No.443/172 /Huk/Dinkes tentang Gerakan sosialisasi penggunaan masker. ${ }^{39}$ Data-data kajian tersebut belum total bersifat transparan, sehingga para akademisi atau tim riset ilmiah tidak dapat menemukan bukti visual untuk dianalisa. Hal ini menyebabkan kualitas kajian ilmiah terhadap kebijakan yang diberlakukan akan cenderung kurang objektif karena hanya didukung oleh pemberitaan media.

International Article yang berjudul "Review and analysis of current responses to COVID-19 in Indonesia: Period of January to March 2020" menyatakan bahwasanya transparansi data sebagai respon awal telah dikritisi oleh beberapa media. Setidaknya sejak 11 Maret 2020, publik sudah mulai kritis menuntut transparansi data kepada pemerintah yang muncul di media berita digital. Kurangnya transparansi data akan menyebabkan kesimpangsiuran informasi, sehingga hanya menambah kepanikan masal dan mengurangi resiliensi masyarakat terhadap keputusan pemerintah dan informasi media. Namun dengan belum totalnya transparansi, mendukung pentingnya publikasi akademis untuk menimbang dari berbagai segi ilmiah. ${ }^{51}$

Diluar dari transparansi data, kesiapan daerah sesuai kajian epidemiologi (berdasarkan kajian kesiapan daerah dan prevalensi kasus) untuk memberlakukan PSBB di Kota Depok kemudian resmi disetujui dan dimulai tanggal 29 April - 12 Mei 2020 melalui Surat Keputusan Wali Kota Depok No.443/198/ Kpts/Dinkes/Huk Tahun 2020.

Perpanjangan PSBB di Kota Depok yang diberlakukan hingga tahap ke III diketahui berhasil mengubah zona merah menjadi zona kuning. ${ }^{37}$ Perpanjangan tahap IV PSBB akan tetap diberlakukan hingga 04 Juni 2020 untuk menyesuaikan secara bertahap pemberlakukan PSBB proporsional.

Dapat dipastikan pelaksanaan PSBB Proporsional sesuai dengan Peraturan Wali Kota Depok No.37 tahun 2020, tentang Pedoman PSBB Proporsional Sesuai Level Kewaspadaan Sebagai Persiapan Pelaksanaan Adaptasi Kebiasaan Baru untuk Pencegahan dan pengendalian COVID-19 akan berlangsung dari tanggal 05 Juni sampai 02 Juli 2020 dan seterusnya menyesuaikan dengan jadwal DKI Jakarta.

\section{Analisis Aktor (Actors Analysis)}


Keterlambatan pemerintah pusat dalam mengambil momentum sentralisasi informasi akan memberikan peluang pada pemerintah daerah untuk bergerak sendiri tanpa adanya kesamaan narasi, karena akan menimbulkan tidak sinkronnya mitigasi pada tiap daerah. ${ }^{47}$

Didukung oleh Journal of CSIS (Centre for Strategic and International Studies) Commentaries Indonesia bahwa segala macam keputusan pemerintah akan memiliki efek samping. Karena itu, memerlukan dua komponen utama dalam perumusan dan tindakan yaitu kolaborasi dan transparansi. ${ }^{47}$

Wali Kota Depok sudah memberlakukan kolaborasi multisektor hingga keterlibatan Satuan Polisi Pamong Praja (Satpol PP) dan Kepala perangkat sosial dan/atau Kesehatan, Kepala sekolah, Camat, Lurah, ketua RT dan RW, serta masyarakat umum lainnya. Tujuan kolaborasi ini untuk melakukan tindakan pencegahan dan pengendalian, yakni menunda semua jenis kegiatan belajar mengajar, penutupan tempat hiburan/wisata, serta menunda kunjungan kerja dan pelayanan posyandu dan posbindu yang dalam hal ini diarahkan seluruhnya ke Puskesmas wilayah Depok, namun masih diperlukan optimalisasi yang didukung oleh masyarakat agar dampak positif PSBB dapat dinikmati oleh semua pihak.

Secara cepat Pemkot Depok pun membuat layanan informasi bernama CCC (Crisis Corona Center) untuk mengupdate evidance base dalam membuat internal mapping cases, melakukan screening by phone, serta menjadi media komunikasi risiko khususnya di Depok. Pasalnya, kekosongan informasi yang tersentralisasi memberikan ruang kepada conflict entrepreneur untuk menciptakan hoax dan disinformasi masif. Poin ini demi menjaga kredibilitas informasi yang bisa dipegang semua pihak. ${ }^{47}$ Selain itu, Pemprov juga melakukan sosialisasi audio di sepanjang kompleks kelurahan di Kota Depok. Namun, tidak sedikit warga yang memberikan komentar di media sosial Instagram @pemkotdepok bahwa masih ada daerah yang belum mendengarkan sosialisasi tersebut. ${ }^{41}$

Pemkot juga melakukan Pemberlakuan Pembatasan Sosial Kampung Siaga (PSKS) tingkat RW yang melibatkan kerjasama warga. Sebanyak 31 RW (19 kelurahan) yang diberlakukan PSKS setelah masa PSBB tahap IV dan berakhir di tanggal 04 Juni 2020 ternyata mengalami penurunan jumlah yaitu tersisa $25 \mathrm{RW}$ yang terkonfirmasi area positif. Untuk itu, PSKS hanya dilanjutkan di wilayah RW tersebut. ${ }^{7}$ Hal ini diupayakan untuk menurunkan dan memperketat mobilisasi penduduk. Di Filipina, pelaksanaan ECQ/karantina ketat dari pemerintah daerah dinyatakan keefektifannya menurunkan tingkat mobilitas penduduk juga, sehingga bukan dikenal sebagai lockdown melainkan upaya 'memaksa' terjadinya social distancing. ${ }^{48}$

\section{Analisa Konteks (Context Analysis)}

Pemerintah diharapkan memiliki strategi penatalaksanaan untuk memenuhi kebutuhan akibat dampak COVID-19 yang dialami masyarakat, seperti (1) Sektor Pendidikan. Para pengajar dituntut mempunyai metode belajar kreatif agar menghidupkan semangat belajar siswa. Akan tetapi, fasilitas elektronik belum tentu secara merata terfasilitasi, wilayah geografis yang kurang mendapatkan koneksi, biaya aplikasi yang cukup mahal, hingga tugas-tugas yang menjadi tanggung jawab lebih bagi para orang tua. Kesiapan untuk Sistem Pendidikan Darurat dibutuhkan sebagai strategi mengupayakan keefektifan proses belajar mengajar khususnya di era COVID-19; (2) Sektor ekonomi yang tidak seimbang, menghambat masyarakat dalam bekerja dan memperoleh pemasukan. Didukung oleh Journal CSIS Commentaries Indonesia menyatakan bahwa sebaran tingkat pengangguran di masa pandemi (Indonesia) berkonsentrasi di sekitar wilayah episentrum yakni Jabodetabek. ${ }^{48} \mathrm{Hal}$ ini tentu akan berdampak pada psikologi serta hubungan sosial. Tidak heran tingkat kekerasan baik dalam keluarga maupun tindak kriminal di lingkungan sosial mulai bermunculan di Kota Depok. Kasus ini dimulai pada bulan April lalu, yakni (1) Pencurian kendaraan roda dua di Kelurahan Sukatani, Tapos; (2) Perampokan di Jl. Raya Juanda, Kelurahan Mekarjaya, Sukmajaya; (3) Pencurian dan kekerasan di sebuah minimarket J1. Bulak Timur, Kecamatan Cipayung; serta (4) Kasus pembunuhan di Situ Pengarengan, Kelurahan Cisalak, Sukmajaya ${ }^{45}$ yang terjadi pada masa COVID-19.

Kementerian Keuangan mengumumkan stimulus ekonomi untuk menangani dampak 
penyebaran COVID-19 di Indonesia melalui alokasi APBN sebesar Rp 405,1 triliun. Dalam anggaran tersebut, terdapat alokasi untuk JPS sebesar Rp110 triliun. ${ }^{52}$ Pemerintah meningkatkan alokasi anggaran untuk masing-masing program bantuan sosial seiring dengan meningkatnya rumah tangga golongan miskin.

Per Agustus 2019, pekerja informal di Indonesia meliputi $55,72 \%$ dari total tenaga kerja. ${ }^{53}$ Sebagian besar tenaga kerja mengandalkan upah harian untuk memenuhi kebutuhannya. Ini mengindikasikan bahwa pekerja informal tidak memiliki tabungan sebagai jaring pengaman di tengah situasi saat ini.

Cynthia Ratih Susilo, Strategic Advisor UN-Habitat dan Senior research fellow di Resilence Development Initiative, mengemukakan bahwa diperlukan pemetaan spasial (spatial mapping) untuk kantung-kantung masyarakat miskin yang kira-kira rentan akan bahaya kesehatan. Hal ini untuk memudahkan adanya evakuasi darurat masyarakat yang tidak tersentuh informasi ataupun yang tidak memiliki kemampuan mitigasi individual. Tidak mungkin penyebaran bisa ditahan tanpa memperhatikan kelompok ekonomi miskin dan rentan tersebut. ${ }^{47}$

Diketahui Pemkot Depok telah mengatur pemberian bantuan dana sosial berdasarkan penetapan besaran JPS di Depok. Namun, pada dasarnya bantuan sosial untuk penanganan COVID-19 tidak hanya berfokus pada satu program, tetapi terdiri dari Program Keluarga Harapan (PKH), Kartu Prakerja, Kartu Sembako, Subsidi Listrik, dan Subsidi Insentif Perumahan Murah. Pemetaan ini diperlukan untuk mengidentifikasi alokasi anggaran, ${ }^{52}$ namun tidak semua masyarakat memahami hal ini. Berita adanya bantuan sosial dari pemerintah meningkatkan kepuasan masyarakat karena merasa pemerintah akan memenuhi kebutuhan mereka lainnya. Tetapi, pada kenyataanya, prosedural yang terjadi tidak sepenuhnya dikomunikasikan.

Pada Mei 2020 Gubernur Jawa Barat menambahkan $37.735 \mathrm{KK}$ penerima bantuan sosial di Kota Depok, yakni bagi yang merupakan kelompok yang tercatat dalam non-DTKS. Sebelumnya Pemprov Jawa Barat menetapkan $10.423 \mathrm{KK}$ penerima bantuan sosial dari data DTKS. Artinya, total penerima bantuan sosial di Kota Depok sebanyak 48.158 KK.
Wali Kota menegaskan bahwa bantuan dana APBD Kota Depok bernilai sebesar Rp.250.000 per KK untuk 30.000 KK dari data non-DTKS. Sudah disalurkan pula bantuan dana APBD Provinsi Jawa Barat ke masyarakat senilai Rp500.000 (dalam bentuk uang tunai Rp.150.000 dan dalam bentuk barang senilai Rp.350.000 kepada $1.000 \mathrm{KK} / \mathrm{KPM}$ ). Distribusinya dilakukan secara langsung dengan jasa Pos (by name, by address). Hal ini karena proses pembagian sebelumnya terdapat masalah koordinasi RT dan RW, sehingga ada keluhan yang mengira adanya pemotongan dana bantuan. Meskipun demikian, distribusi bantuan sosial tetap mengalami kendala. Dari $10.423 \mathrm{KK}$ yang dijanjikan, hanya $2.191 \mathrm{KK}$ (21\%) yang sudah menerima bantuan sosial sejak 15 April hingga 05 Mei 2020. Hal ini menunjukan kurang optimalnya pemetaan spasial, kordinasi dan komunikasi dari pemkot dan berdampak pada distribusi ke masyarakat.

Secara structural, harusnya koordinasi buttom-up diaktifkan di lingkungan masyarakat, agar lebih transparan, terinformasi dan meringankan kerja pemerintah tanpa perlu memperlihatkan kerentanan fundamental. ${ }^{47}$ Namun, secara sociocultural, efek positif dari COVID-19 secara langsung merubah pola hidup masyarakat untuk memberlakukan Pola Hidup Bersih dan Sehat (PHBS).

\section{Analisa Proses Kebijakan (Policy Process Analysis)}

Pelaksanaan PSBB menuntut adanya inspeksi lebih untuk mencapai keefektifan pelaksanaan kebijakan tersebut. Solusi terkait metode belajar dari rumah memang belum dapat dioptimalkan, misalnya; ujian nasional (UN) yang akhirnya tidak dilaksanakan/dihapus, nilai akademik yang sulit diukur secara objektif, dan efek penerimaan materi belajar dari siswa yang tidak maksimal. Selain itu kontribusi orang tua yang tidak merata dalam membantu proses belajar mengajar sangat berpengaruh pada nasib pendidikan di masa darurat.

Bagi sebagian sekolah yang latar belakangnya tergolong kelompok ekonomi menengah atau tinggi, adaptasi menuju era e-learning system dengan mudah diadaptasikan. Efek positif yang diterima adalah siswa dengan mudah mengenal aplikasi-aplikasi baru dan 
lebih dekat dengan teknologi untuk memberi keuntungan terhadap pola pikir digital. Namun, pengaturan metode tersebut dapat berhasil ketika feedback siswa seimbang secara kualitas dan kuantitas. Bila prosesnya tidak cukup dinikmati, maka metode belajar dari rumah membutuhkan kurikulum darurat.

Sebanyak 889 sekolah di Kota Depok, sangat diharapkan adanya progres dan laporan berkala yang diberikan ke Dinas Pendidikan untuk dievaluasi. Hal ini bertujuan untuk menilai tingkat keefektian pelaksanaan sistem daring.

Disamping sektor pendidikan, beberapa tempat umum juga membantu sektor kesehatan dengan mewajibkan semua tempat umum memiliki tempat CTPS dan pelaksanaan check point yang terkoordinir. Terlihat hampir di semua tempat umum di Kota Depok telah menjalankan protokol tersebut. Hasil riset yang awalnya menilai protokol ini kurang optimal, setidaknya sudah dapat ditanggulangi dengan baik, tepat dan konsisten.

Melihat peningkatan status epidemiologi, COVID-19 belum dapat ditekan secara bermakna, maka pemerintah dapat mengupayakan untuk mewajibkan setiap lembaga dan instansi memiliki departemen darurat, agar mempermudah intervensi cepat tanggap dan membantu updating data. Perlu diperhatikan juga terkait pembentukan SATGAS khusus Jabodetabek untuk lebih cepat lebih melakukan tracing area serta penanganan darurat yang tanggap dan spesifik.

Keterbatasan dalam mengakses dokumen kebijakan secara online menjadi kendala utama dalam penelitian ini. Kendala berikutnya adalah tim peneliti tidak menemukan penelitian serupa di wilayah Depok terkait kebijakan COVID-19 yang bisa dijadikan benchmark.

\section{KESIMPULAN}

Kebijakan PSBB di Kota Depok perlu mendapat apresiasi karena pelaksanaan operasional yang sinergis, multisektor dan dinamis. Hal ini terbukti melalui empat tahap perpanjangan PSBB, Kota Depok berhasil mengubah status zona merah menjadi zona kuning yang secara epidemiologi dibuktikan dengan angka Reproduksi Efektif (Rt) yakni telah menurun dari 1,39 di tanggal 25 Mei menjadi 0,54 di tanggal 8 Juni 2020 yang artinya dapat dipersiapkan untuk memberlakukan PSBB Proporsional.

Melalui analisa swot dapat terlihat bahwa evaluasi yang kami rangkum sebagai rekomendasi strategi untuk memaksimalkan pelaksanaan kebijakan selanjutnya baik dari totalitas implementasi, fungsi kontrol, dan evaluasi berkala.

\section{SARAN}

Berikut beberapa rekomendasi tim peneliti kepada Pemkot Depok:

1. Tingkatkan pengawasan dan evaluasi efektifitas sistem pembelajaran PJJ

Kolaborasi dengan Dinas Pendidikan untuk melakukan updating data laporan kerja dari setiap pengajar/sekolah sebagai evaluasi keefektifan pelaksanaan PJJ dan sekaligus sebagai bahan evaluasi untuk pendidikan darurat yang merata.

2. Pengadaan Departemen Darurat Kesehatan Penting untuk memberlakukan pengadaan Departemen Darurat Kesehatan di setiap Lembaga/Instansi yang sigap kelola masalah kesehatan darurat.

3. Tingkatkan kolaborasi dan pemberdayaan masyarakat

Penentapan Kampung Siaga dengan pelaksanaan PTKS sudah sangat baik. Namun, masyarakat memerlukan reward untuk mempertahankan koordinasi mandiri yang sigap pada keadaan darurat secara terkontrol.

4. Tingkatkan transparansi JPS terkait laporan Bansos untuk DTKS dan nonDTKS.

Pemerintah sebaiknya mempertimbangkan mekanisme self-reporting bagi yang terdampak dan membutuhkan bantuan, atau lebih mudahnya membuat pemetaan spasial sesuai dengan JPS baik untuk kelompok DTKS maupun Non DTKS dan diinformasikan secara jelas dan reguler, agar masyarakat paham mengenai bantuan yang akan diberikan serta mekanismenya. Pemerintah juga bisa bekerja sama dengan lembaga lain atau pihak swasta, terutama start-up yang memberdayakan kelompok-kelompok yang rentan.

5. Kolaborasikan untuk membentuk SATGAS khusus Jabodetabek.

Hal ini merupakan rekomendasi dari tim dan juga stakeholder saat pelaksaan seminar, yang 
diajukan untuk mendapatkan perhatian khusus dari Pemkot dan sebagai kebijakan yang lebih bersifat sektoral.

\section{UCAPAN TERIMA KASIH}

Peneliti mengucapkan terima kasih kepada Seluruh Jajaran Pemkot Depok termasuk Dinkes Depok dan Fakultas Kesehatan Masyarakat Universitas Indonesia, khususnya Program Pascasarjana yang juga turut memberikan apresiasi terhadap artikel kami dan ikut mendukung rekomendasi yang kami buat.

\section{DAFTAR REFERENSI}

1. Subdit Penyakit Infeksi Emerging, Dit. Surkarkes, Ditjen P2P. Materi Pelatihan Relawan Covid-19 area Jabodetabek. Jakarta: 2020.

2. Report Centers for Disease Control and Prevention (CDC). Coronavirus Disease 2019 (COVID-19). 2020.

3. World Health Organization. Report of the WHO-China Joint Mission on Coronavirus Disease 2019 (COVID-19) on 05th March 2020.

4. WHO. Naming the coronavirus disease (COVID-19) and the virus that causes it. 2020 Jun (2020 Juni 21). Available from: https://www.who.int/emergencies/diseases/no vel-coronavirus-2019/technicalguidance/naming-the-coronavirus-disease(covid-2019)-and-the-virus-that-causes-it.

5. Situation Report-152 by WHO from national authorities by 10:00 CEST on 20th June 2020 .

6. Laporan Gugus Tugas Percepatan Penanganan Coronavirus Disease (COVID-19) Depok. Informasi Perkembangan Covid-19 Kota Depok. 2020 June 16.

7. BeritaSatu. Depok Jadi Zona Merah, Kasus Covid-19 Tersebar di 56 Kelurahan [Video YouTube]. Available from: https://youtu.be/P2IfAtddZyI, 2020 June 17.

8. Jin Hun S, Kang Ji H, Cho MG, Lee SY, and Kang HJ. 2020. Current strategies for the control of COVID-19 in South Korea: Research Article. Korea Selatan: Department of Animal Science and Technology, Chung-Ang University, Anseong, Korea.

9. Siedner M, Harling G, Reynolds Z, Gilbert R, Atheendar S, Venkataramani, and Alexander C. 2020. Social Distancing to Slow the U.S. COVID-19 Epidemic: Interrupted Time-Series Analysis. USA: Medical Practice Evaluation Center Massachusetts General Hospital.

10. Viner RM, Russell SJ, Croker H, Packer J, Ward J, Claire S, Mytton O, Bonell C, and
Booy R. 2020. School Closure and Management Practices During Coronavirus Outbreaks Including COVID-19: A Rapid Systematic Review.

11. Kong Siu C, Chan TW, Huang R, Cheah HM. 2014. A review of e-Learning policy in school education in Singapore, Hong Kong, Taiwan, and Beijing: implications to future policy planning. Journal Computerize Education.

12. CNBCIndonesia.com. Besok PSBB Berlaku di Jakarta, Ini Lockdown. [09th April 2020]. Available from: https://www.cnbcindonesia.com/news/20200409183032-4150989/besok-psbb-berlaku-di-jakartaini-lockdown-bukan-sih. 202021 st June.

13. Müller O, Guangyu, Jahn A, dan Razum O. 2020. COVID-19 Control: Can Germany Learn from China? International Journal Health Policy and Management. Germany: Kerman University of Medical Sciences.

14. Undang-Undang Republik Indonesia Nomor 6 Tahun 2018 Tentang Kekarantinaan Kesehatan.

15. Peraturan Pemerintah Nomor. 21/2020 Penetapan PSBB oleh Presiden RI.

16. Peraturan Menteri Kesehatan Republik Indonesia Nomor 9 Tahun 2020, Tentang Pedoman Pembatasan Sosial Berskala Besar Dalam Rangka Percepatan Penanganan Covid-19.

17. Keputusan Gubernur Jawa Barat Nomor 443/Kep.221-Hukham/2020 Tahun 2020 Pemberlakuan Pembatasan Sosial Berskala Besar di Daerah Kabupate Bogor, Daerah Kota Bogor, Daerah Kota Depok, Daerah Kabupaten Bekasi, dan Daerah Kota Bekasi dalam Rangka Percepatan Penanganan Covid19.

18. KOMPASTV. 2020. Belum Aman, Ini Dia Beberapa Wilayah Jabar yang Harus Perpanjang PSBB (Video Youtube]. Available from: https://youtu.be/Ny0dOWB2rrI. 2020 June 14.

19. Kompas.com. Belum Sanggup Redam Penularan Covid-19, PSBB di Depok Dinilai Butuh Perbaikan Serius. [2020, 5 Mei]. Available from: https://megapolitan.kompas.com/read/2020/0 5/05/14062231/belum-sanggup-redampenularan-covid-19-psbb-di-depok-dinilaibutuh. 2020 June 17.

20. CNNIndonesia.com. Pemkot Depok Revisi Perwal, Beri Sanksi Pelanggar PSBB. Available from: https://www.cnnindonesia.com/nasional/2020 0506175023-20-500832/pemkot-depok- 
revisi-perwal-beri-sanksi-pelanggar-psbb. 2020 June 26.

21. Depok.pikiran-rakyat. Lembaga Riset Kritisi PSBB di Depok Lemah, Berikut Tiga Catatan Penting untuk Wali Kota. Available from: https://depok.pikiran-rakyat.com/lokaldepok/pr-09377260/lembaga-riset-kritisipsbb-di-depok-lemah-berikut-tiga-catatanpenting-untuk-wali-kota. 2020 June 26.

22. Sindonews.com. Riset Urban Policy. Kebijakan Penanganan Corona di Kota Depok. Available from: https://daerah.sindonews.com/read/18369/70 1/riset-urban-policy-kebijakan-penanganancorona-di-kota-depok-lemah-1588683959. 2020 June 26.

23. Raoofi A, Takian A, Sari AA, Olyaeemanesh A, Haghighi H, and Aarabi M. 2020. COVID19 Pandemic and Comparative Health Policy Learning in Iran: Article Iran Medicine. Collaboration Study between Tehran University of Medical Sciences, Tehran, Iran; Mazandaran University of Medical Sciences, Sari, Iran; and Azad University (IR) in Oxford, Oxford, UK.

24. Wang Jia and Wang Zhifeng. 2020. Strengths, Weaknesses, Opportunities and Threats (SWOT) Analysis of China's Prevention and Control Strategy for the COVID-19 Epidemic. International Journal of Environment Reseacrh and Public Health. Beijing: Peking University School of Public Health, Beijing.

25. Saraisky, N. G. 2015. Analyzing Public Discourse: Using Media Content Analysis to Understand the Policy Process, Current Issues in Comparative Education.

26. Araújo Jr, J. L. C. de and Maciel Filho, R. 2001. 'Developing an operational framework for health policy analysis', Revista Brasileira de Saúde Materno Infantil.

27. WHO. 2018. The Politics of Policy Change in Low and Middle-Income Countries. Available from: https://www.who.int/alliance$\mathrm{hpsr} /$ resources/publications/Alliance-HPAReader-web.pdf. 2020 21st June.

28. Walt G. 1994. Health Policy: An Introduction to Process and Power. London: Zed Books.

29. Walt $\mathrm{G}$ dan Gilson L. 1994. Reforming the health sector in developing countries: The central role of policy analysis. Health Policy and Planning. London: Zed Books.

30. Temesvari, N.A. 2018. Analisis Segitiga Kebijakan Kesehatan Dalam Pembentukan Peraturan Menteri Pendayagunaan Aparatur Negara Dan Reformasi Birokrasi Republik Indonesia Nomor. 30 Tahun 2013 Tentang Jabatan Fungsional Perekam Medis Dan
Angka Kreditnya. Indonesian of Health Information Management Journal.

31. Ayuningtyas. 2014. Kebijakan Kesehatan Prinsip dan Praktik (1es ed). Jakarta: Rajawali Perss.

32. Gurning, F. P. 2018. Dasar Administrasi \& Kebijakan Kesehatan Masyarakat (M. Y. Pratama, ed.). Yogyakarta: K-Media.

33. Hajijah Sri. 2019. SKRIPSI: Analisis Implementasi Kebijakan Penurunan Stunting Di Desa Secanggang Kabupaten Langkat. Universitas Islam Negeri: USU.

34. LBH Jakarta. 2020. Kertas Posisi: Penanganan Wabah Pandemi COVID-19 dan Penerapan PSBB di Jabodetabek Harus Memperhatikan Hak Asasi Manusia dan Pemenuhan Hak Warga. Jakarta.

35. BBC News Indonesia. Covid-19: Istilah R 'angka reproduksi' untuk memahami ancaman virus corona. Availble from: https://www.bbc.com/indonesia/majalah52733733. 2020 June 29.

36. Fajar, M. 2020. 'Estimation of COVID-19 reproductive number case of Indonesia (estimasi angka reproduksi novel coronavirus (COVID19), ResearchGate, (March), pp. 1-7. doi: 10.13140/RG.2.2.32287.92328.

37. Kompas.com. Wali Kota Depok Klaim Angka Reproduksi Covid-19 Menurun 2 Pekan Terakhir Halaman all. Available from: https://megapolitan.kompas.com/read/2020/06/10/13265011/ wali-kota-depok-klaim-angka-reproduksicovid-19-menurun-2-pekan-terakhir?page=all. 2020 June 29.

38. Surat Edaran No.443/172/Huk/Disperindag, tentang Pengaturan Kegiatan Usaha Ritel, Grosir Maupun Eceran, Supermarket, Minimarket, dan Toko Swalayan.

39. Surat Edaran No.443/172/Huk/Dinkes tentang Gerakan Sosialisasi Penggunaan Masker.

40. Radardepok.com Depok Dinilai Kemenkes, Hasilnya 2 Hari Lagi. Available from: https://www.radardepok.com/2020/04/psbbdepok-dinilai-kemenkes-hasilnya-2-harilagi//. 2020 June17.

41. Instagram Pemerintah Kota Depok [@pemkotdepok]. (2020, 24 Maret). Depok Bergerak (Video Instagram). Available from: https://www.instagram.com/pemkotdepok/?hl=id. 2020 June 21.

42. Kompas.com. Sebulan Tangani COVID-19 Gugus Tugas Tingkatkan Laboratorium untuk Uji Spesimen [2020, 24 April]. Available from: https://nasional.kompas.com/read/2020/04/14/1753447 1/sebulan-tangani-covid-19-gugus-tugas- 
tingkatkan-laboratorium-untuk-uji. 2020 June 20.

43. Suryani Dini. 2020. Peran Masyarakat Sipil dalam Mengahadapi COVID1-19: Pusat Penelitian Politik. LIPI.

44. Peraturan Gubernur Jawa Barat Nomor.4 Tahun 2020. Pedoman Pengenaan Sanksi Terhadap Pelanggaran Pelaksanaan Pembatasan Sosial Berskala Besar dalam Penganggulangan COVID-19) di Daerah Kabupaten Bogor, Kota Bogor, Kota Depok, Kabupaten Bekasi dan Kota Bekasi.

45. Moralez AJR, Ospina JAC, Ocampo EG, et all., 2020. Internation Journal "Clinical, laboratory and imaging features of COVID19: A systematic review and meta-analysis. Elsevier Public Health Emergency Journal. USA. Available from: https://www.ncbi.nlm.nih.gov/pmc/articles/P MC7102608/ 2020 28th June

46. Rodriguez-Morales AJ, Gallego V, EscaleraAntezana JP, Mendez CA, Zambrano LI, Franco-Paredes C, et al. COVID-19 in Latin America: The implications of the first confirmed case in Brazil. Travel Med Infect Dis [Internet]. 2020;101613 Feb 29 [cited 2020 Mar 23]. Available from: http://www.ncbi.nlm.nih.gov/pubmed/ 32126292. 2020 28th June

47. Edbert Gani Suryahudaya. 2020. Transparansi, Kolaborasi, dan Resiliensi Kota di Tengah Pandemi COVID-19. CSIS Commentaries Indonesia DMRU-004. Availabel from

https://www.csis.or.id/publications/transpara nsi-kolaborasi-dan-resiliensi-kota-di-tengahpandemi-covid-192020 Aug 07.

48. Ari Perdana. 2020. Lockdown in Philipina: in the Philippines: Some Early Lessons for Mitigating COVID-19. Journal of CSIS Commentaries DMRU-014. Availble from: https://www.csis.or.id/publications/karantinawilayah-di-filipina-beberapa-pelajaran-awaluntuk-mitigasi-covid-19. 2020 07th August.

49. Koo JR, Cook AR, Park M, Sun Y, Sun H, Lim JT, et al. Interventions to mitigate early spread of SARS-CoV-2 in Singapore: a modelling study. Lancet Infect Dis [Internet]. 2020; Mar [cited 2020 Mar 24];0(0). Available from: https://linkinghub.elsevier.com/retrieve/pii/S1473309920301626.

50. Amelinda Bonita Leonard. 2020. Pentingnya Inovasi Kepemimpinan dan Civic Engagement di Daerah dalam Menghadapi COVID-19. Available from : https://www.csis.or.id/publications/pentingny a-inovasi-kepemimpinan-dan-civic- engagement-di-daerah-dalam-menghadapicovid-19/2020 Aug 07.

51. Riyanti Djalante, Jonatan Lassa, Davin Setiamarga. 2020. Review and analysis of current responses to COVID-19 in Indonesia: Period of January to March 2020. Progress in Disaster Science 6 (2020) 100091 on Journal ELSEVIER. Available from : https://www.sciencedirect.com/science/articl e/pii/S2590061720300284 2020 07th August

52. Barany L J, Simanjuntak Indira, Widya D A, Damuri Y R. 2020. Bantuan Sosial Ekonomi di Tengah Pandemi COVID-19: Sudahkah Menjaring Sesuai Sasaran?. Journal of CSIS Commentaries ECON-002-ID. Available from

https://www.csis.or.id/publications/bantuansosial-ekonomi-di-tengah-pandemi-covid-19sudahkah-menjaring-sesuai-sasaran 2020 Aug 07.

53. SAKERNAS. 2019. Badan Pusat Statistik.

54. Yaset C O, Rebellón S D A, Peñaloza R M. 2020. Effective Reproductive Number estimation for initial stage of COVID-19 pandemic in Latin American Countries. International Journal of Infectious Diseases : ELVISIER. Available from : https://www.sciencedirect.com/science/articl e/pii/S120197122030285X 2020 07th August 